\title{
CONGRESSO JURIDICO IBERO-AMERICANO
}

A Ernesto Lehr, secretario do Instituto de direito internacional, devemos as informaçôes, $\left({ }^{*}\right)$ por elle obtidas de Torres Campos, professor na universidade de Granada, concernentemente ás materias discutidas no congresso ibero-americano, reunido em Madrid, ha dois annos, sob a presidencia de CANOvas DE CAstilho, então primeiro ministro do gábinete hespanhol.

Sem publicidade, o congresso, composto de delegados dos governos, dos supremos tribunaes de justiça, das universidades, e das grandes corporaçóes scientificas, tanto da Hespanha e de Portugal, como tambem das republicas americanas, que foram colonias d'esses paizes, tractou d'uma serie interessante de questões de direito internacional.

A primeira questão submettida ao congresso foi a do arbitramento, "como meio de resolver os litigios, que possam surgir, on que pendam de decisão entre a Hespanha, Portugal, e os estados ibero-americanos.s

Foram votadas as seguintes proposições:

"1. $\left.{ }^{\circ}\right)$ E' conveniente 0 arbitramento no estado actual da sociedade internacional, afim de aplanar os conflictos internacionaes;

. 2. $\left.{ }^{\circ}\right)$ Sua acceitação pela America latina, Hespanha e Portugal, seria opportuna na actualidade,

(*) Revue de législation comparée, Tom. XXVI, 1894, n.o 3, pag. 355 
-3. ${ }^{\circ}$ Para este effeito, os Estados representados no congresso devem negociar tratados especiaes de arbitramento, tomando por base a convenção entre a Hespanha e o Equador, datada de 23 de Maio de 1888, até que os progressos do direito internacional publico tornem possivel a organisação d'um tribunal permanente, destinado a liquidar, ou a prevenir as questões, que possam levantar-se entre os mesmos Estados;

"4. $\left.{ }^{\circ}\right)$ Devem ser submettidos ao arbitramento todos os conflictos internacionaes, sem excepção.s

Estes principios, proclamados pelo congresso, são de indiscutivel vantagem. A difficuldade, porém, geralmente reconhecida, versa sobre os meios de assegurar a efficacia do arbitramento.

$O$ congresso não resolveu o problema.

$\left.\varangle 5 .^{\circ}\right)$ Toda sancção material, originando graves difficuldades, outros meios de tornar efficaz uma decisão arbitral não existem, além d'uma organisação juridica dos Estados ibero-americanos. Mas, como tal organisação ressente-se ainda de serios obstaculos, mesmo entre povos tão intimamente ligados, importa, que esse ideal faça objecto de novos trabalhos doutrinarios, e que a questão seja inscripta na ordem do dia de todos os congressos futuros, afim de não ser esquecida; e que, pelo menos, o principio do arbitramento seja, desde logo, geralmente acceito.s

$$
* *
$$

Intitulava-se a segunda questão, d'um caracter mais especial: - meios de tornar efficazes na Hespanha, em Portugal, e nas republicas ibero-americanas, as obrigações civis contrahidas em um dos referidos paizes, as diligencias, vias probatorias, e as decisões de seus respectivos tribunaes.s 
Eis as soluções dadas pelo congresso:

a) Em regra, a validade extrinseca d'um contracto deve ser apreciada pela lex loci; mas o congresso admittiu, que o contracto tambem pudesse ser celebrado de accordo com a lei nacional das partes contractantes, ou com a lex rei sitce, contanto que não repugnem á ordem publicá; e que, si possivel fôr, seja a fórma aperfeiçoada de harmonia com a lei do paiz onde o mesmo contracto tenha de ser executado;

b) As sentenças proferidas por um tribunal estrangeiro, em materia civil, devem ser executadas, sem dependencia de reciprocidade, sob as unicas seguintes condições :

1. ${ }^{\circ}$ competencia dos tribunaes;

$2 .^{\circ}$ authenticidade da sentença;

$3 .^{\circ}$ que a obrigação seja reputada licita no paiz em que a lecisão deve executar-se;

$4 .^{\circ}$ que a sentença não tenha sido proferida por contumacia;

$5 .^{\circ}$ que não repugne ao direito publico interuo do paiz da execuçâo, nem contrarie os principios do direito internacional, adoptados pelas nações representadas no congresso;

6. ${ }^{\circ}$ que, tractando-se d'uma sentença arbitral, seja a execução promovida perante as justiças ordinarias competentes.'

Quanto ás sentenças criminaes, devem ser executadas da mesma maneira, no que concerne á responsabilidade civil, mas não no que respeita ás penas.

- Para applicação das penalidades áquelles que n ellas incorreram no territorio estrangeiro, a extradição dependerá de tratados, e poderão determinal-a os crimes communs, cuja pena corporea exceder a um 
anno; comtanto que sejam previstos pelo codigo penal do paiz requerido, e que, segundo o mesmo, não estejam prescriptos.»

$$
*^{*}{ }^{*}
$$

Derogando as regras habitualmente acceitas, relativamente á "Propriedade litteraria, artistica e indus-

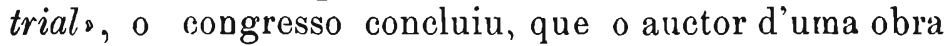
artistica ou litteraria deve gozar do seu direito durante oitenta annos, "sendo este periodo admittido como uma transição entre a perpetuidade e a limitação a prazos mais curtos.»

Os estrangeiros devem gozar, n'esses paizes, dos mesmos direitos, que os nacionaes.

Os julgamentos das violações ao direito de auctor devem ser proferidos pelos tribunaes, e segundo as leis do paiz onde ellas forem commettidas.

Em materia industrial, o congresso propoz a instituição de jurados, incumbidos de resolverem as questões civis ou criminaes, que se relacionarem com os direitos de propriedade industrial.

$$
\text { ** } *
$$

Com respeito ás questões de "abordagem», o congresso adheriu aos principios formulados nos congressos de direito commercial, reunidos na Belgica; proclamando, além disso, a necessidade de punir a recusa de soccorros em alto mar, caso pudessem ser fornecidos.

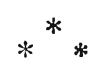

A ultima questão discutida pelo congresso, denominava-se: - Regras do casamento e do divorcio, no direito internacional privado.» 
Foram estas as conclusões adoptadas:

a) A capacidade dos futuros conjuges determina-se, segundo a lei pessoal de cada um d elles;

b) Toda formalidade propriamente dita, relativa á celebração do casamento, rege-se pela lei do lugar da celebração ;

c) Todavia, os casamentos celebrados perante um agente diplomatico, ou consular competente para effectual-os, regulam-se, quanto á fórma, pela lei do paiz por elle representado.*

Finalmente, as causas de divorcio, ou de separação, determinam-se pela lei pessoal dos conjuges, a menos que essa lei não offenda uma prohibição formal da lex loci.

Dr. Pinto Ferraz. 